\title{
THE INFLUENCE OF THE SWASH PLATE OSCILLATION ON PRESSURE RIPPLE IN VARIABLE DISPLACEMENT AXIAL PISTON PUMP
}

\author{
Xiaochen Huang, Bing Xu, Junhui Zhang* \\ The State Key Laboratory of Fluid Power and Mechatronic Systems, Zhejiang University, No.38 Zheda Road, \\ 310027 Hangzhou, China \\ * Corresponding author: Tel.: +86 153 81058508; E-mail address: benzjh@zju.edu.cn
}

\begin{abstract}
The displacement of the variable displacement pumps can be adjusted by changing the swivel angle of the swash plate. In fact, the swivel angle oscillates because of the oscillating torque on the swash plate, which caused by the pressure fluctuation of the piston chamber. The swivel angle is most often considered as a constant value in previous studies. However, the oscillation of the swash plate leads to an additional movement of the piston, which has an impact on the pressure fluctuation and the flow ripple. In this study, an improved model of a self-supplied variable displacement pump is established. The swash plate oscillation under different operating conditions is presented. In order to investigate the effect of the swash plate oscillation on the pressure ripple, a comparison between the case of the fixed swash plate and the oscillated swash plate is conducted. Results show the pressure ripple with an oscillated swash plate shows a smaller pressure ripple. It also shows that the nine pistons and the control mechanism both affect the pressure ripple and flow fluctuation.
\end{abstract}

Keywords: Variable piston pump, Swash plate, Oscillation, Pressure ripple

\section{INTRODUCTION}

Variable displacement axial piston pumps take a particularly important place in hydraulic systems due to their high power density, high efficiency, and controllability [1]. The swivel angle of the swash plate is adjusted by the control actuator mechanism. As a result, the outlet flow rate of the pump is altered. As volumetric machines, axial piston pumps discharge an oscillating flow rate, which generates the pressure ripple in hydraulic circuits. It's followed by vibrations in the pump component and pipelines, degrading the reliability and durability of hydraulic system. As a technique of the vibration and noise reduction in axial piston pumps, many previous works have focused on geometric optimization of the valve plate to reduce the amplitude of the pressure ripple [2,3]. Most of the investigations are conducted with a fixed swash plate even if the pump has variable displacement $[4,5]$.

However, the swivel angle oscillates because of the oscillating torque on the swash plate caused by the pressure fluctuation in the piston chamber $[6,7]$. Especially, the oscillating movements of the swash plate have been measured by Achten [8] and Fang [9] in a variable displacement floating cup pump and a pressure compensated piston pump, respectively.

In recent years, a few researchers investigated the effect of the swash plate oscillation in the design of the valve plate. Ericson [10,11] studied the swash plate oscillations in a pressurecontrolled axial piston pump by simulation. Large variations of the flow pulsations were showed between fixed and oscillating swash plates. By the simulation of different valve plate configurations, it conducted that the optimised valve plate design would be changed due to the effect of swash plate oscillation on the flow pulsation.

Schoemacker et al [12] investigated the impact of the valve plate design on the torque load. Comparing the results with three valve plate designs using silencing grooves and bores, the influence of the swash plate oscillation on the pump's output flow strongly depends on the valve plate design. The author summarized that the valve plate should be designed according to 
the swash plate control system for a variable displacement pump.

In this study, to investigate the dynamic behavior of the swash plate vibration and the influence of the oscillation on the pressure ripple, an improved model of a self-supplied variable displacement axial piston pump is presented. The oscillation of the swash plate is taken into consideration. The amplitude of the swash plate oscillation at different operating conditions is calculated. To investigate the effect of the swash plate oscillation on the pressure ripple, a comparison between two cases of the fixed swash plate and the oscillated swash plate is conducted. The influence of the oscillation on pumping dynamics and control mechanism dynamics are both discussed.

\section{MATHEMATICAL MODELING}

\subsection{Description of the physical system}

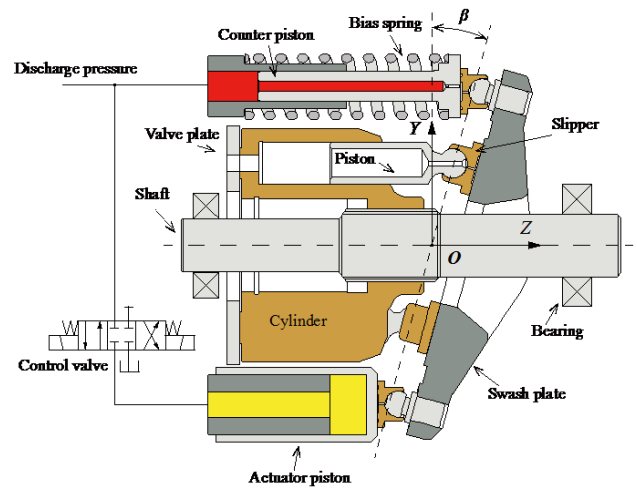

Figure 1: Schematic of the variable displacement pump

Figure 1 shows a schematic of the variable displacement pump. The rotating group rotates with shaft driven by the prime mover. The piston executes the reciprocating motion owing to the inclination of the swash plate. As a consequence, the hydraulic oil flows in and out of the piston chamber. The swash plate swivels with the control flow entering or leaving the actuator piston. And then, the hydraulic displacement of the axial piston pump is changed. In this study, a proportional valve is utilized to control the flow rate of the actuator piston.

\subsection{Piston pump dynamics}

Since the displacement varies with the swash plate angle, the relationship of the swash plate angle and the motion of the piston must be figured out through the kinematics analysis, which can be expressed as

$$
\begin{aligned}
z_{i}= & R \sin \varphi_{i} \tan \beta \\
v & =\dot{z}_{i}=R \omega \cos \varphi_{i} \tan \beta+\frac{R \sin \varphi_{i}}{\cos ^{2} \beta} \frac{d \beta}{d t} \\
a & =\ddot{z}_{i}=\frac{R \sin \varphi_{i}}{\cos ^{2} \beta} \frac{d^{2} \beta}{d t^{2}}+\frac{2 R \sin \varphi_{i} \tan \beta}{\cos ^{2} \beta}\left(\frac{d \beta}{d t}\right)^{2} \\
& +\frac{2 R \omega \cos \varphi_{i}}{\cos ^{2} \beta} \frac{d \beta}{d t}-R \omega^{2} \sin \varphi_{i} \tan \beta
\end{aligned}
$$

The motion of the $\mathrm{i}$-th piston is expressed as

$$
P_{i} \frac{\pi}{4} d^{2}-f_{i}-F_{s i}=m_{p s} \ddot{z}_{i}
$$

The variation rate of pressure in the piston chamber $d P / d t$ can be derived by applying the continuity equation in integral form as follows

$\frac{d P_{i}}{d t}=\frac{K_{e}}{V_{p}}\left(q_{i n, i}-q_{\text {out }, i}-q_{l k, i}-\frac{d V_{p}}{d t}\right)$

where $q_{\text {in }}$ and $q_{\text {out }}$ are the flow rate between the piston chamber and the pump port. It can be described as

$$
\begin{aligned}
& q_{\text {in }, i}=C A_{\mathrm{LP}} \sqrt{\frac{2\left|P_{\text {in }}-P_{i}\right|}{\rho}} \cdot \operatorname{sgn}\left(P_{\text {in }}-P_{i}\right) \\
& q_{\text {out }, i}=C A_{\mathrm{HP}} \sqrt{\frac{2\left|P_{\text {out }}-P_{i}\right|}{\rho}} \cdot \operatorname{sgn}\left(P_{i}-P_{\text {out }}\right)
\end{aligned}
$$

The inlet flow rate $Q_{\text {in }}$ and the outlet flow rate $Q_{\text {out }}$ are the sum of the flow rate from nine pistons.

\subsection{Swash plate dynamics}

The dynamics of the swash plate are dictated by control moments generated by the pumping piston and control mechanism. These can be described as

$J_{s w} \frac{d^{2} \beta}{d t^{2}}+c_{s w} \frac{d \beta}{d t}=M_{p}+M_{a p}+M_{c p}$

where the moment $M_{p}$ is mainly generated by pumping pistons and can be expressed by

$M_{p}=\sum_{i=1}^{N} \frac{R \sin \varphi_{i}}{\cos ^{2} \beta} F_{s i}$ 
It's worth mentioning that the moment $M_{p}$ is the main cause of the swash plate oscillation.

The moment caused by the actuator piston and the counter piston can be respectively described as

$$
\begin{aligned}
& M_{a p}=F_{a p} L_{a p} \cos \beta \\
& M_{c p}=F_{c p} L_{c p} \cos \beta
\end{aligned}
$$

\subsection{Control mechanism dynamics}

The forces on the actuator piston are given by

$m_{a p} \ddot{x}_{a p}=P_{c} A_{a p}-f-F_{a p}$

where the motion of the actuator piston can be written as the function of the swash plate angle as

$x_{a p}=L_{a p} \sin \beta$

The pressure within the actuator piston is governed by the continuity equation as

$\frac{V_{a p}}{K_{e}} \frac{d P_{c}}{d t}=Q_{a p}-A_{a p} \dot{x}_{a p}-Q_{a p l}$

Similarly, the dynamic of the counter piston can be expressed as

$$
\begin{aligned}
& m_{c p} \ddot{x}_{c p}=P_{c p} A_{c p}-f_{c p}-k x_{c p}+F_{s p 0}-F_{c p z} \\
& x_{c p}=L_{a p} \sin \beta \\
& \frac{V_{c p}}{K_{e}} \frac{d P_{c p}}{d t}=Q_{c p}-A_{c p} \dot{x}_{c p}-Q_{c p l}
\end{aligned}
$$

\subsection{Control valve dynamics}

To simplify the analysis, a second-order model is used to compute the dynamics of the proportional valve. It can be written as

$\frac{x_{v}}{u}=\frac{k_{v} \omega^{2}}{s^{2}+2 \xi \omega+\omega^{2}}$

Then, the flow rate entering the actuator piston, $Q_{a p}$ is conducted as

$Q_{a p}=C_{q} x_{v} \sqrt{\frac{2 \Delta p}{\rho}}$

\section{RESULTS AND DISCUSSION}

\subsection{Swash plate oscillation analysis}

In a variable displacement pump, the pressure ripple in the piston chamber results in variant torque load and therefore the control force is altered to satisfy the balance of the swash plate. That's to say, the fluctuation of the torque acting on the swash plate accounts for the oscillation of the swash plate.

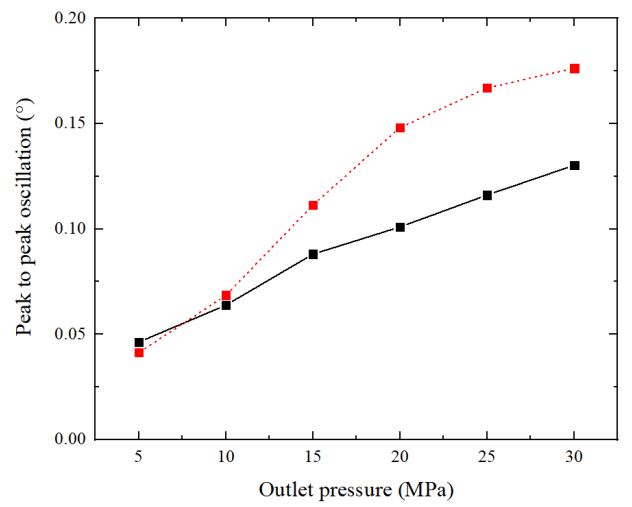

Figure 2: The peak to peak values of swash plate angle under different outlet pressure

Since the oscillation is determined by the torque on the swash plate, it leads us to draw a conclusion that the oscillation has something to do with the outlet pressure. Figure 2 presents a comparison of the oscillations of the swash plate at different pressure when working conditions are $\beta=12^{\circ}, n=1000 \mathrm{rpm}$ (solid line) and $\beta=12^{\circ}$, $n=1200 \mathrm{rpm}$ (dashed line). From the figure, it can be concluded that the swash plate oscillation is positively correlated with pressure, which can be explained as the increasing torque with the pressure.

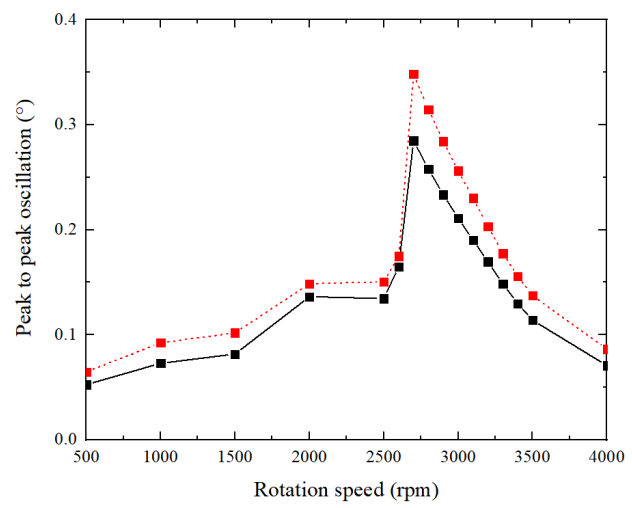

Figure 3: The peak to peak values of swash plate angle under different rotational speed

The peak to peak values of the swash plate angle under different rotational speed are shown in 
Figure 3. Simulations are carried out at $12^{\circ}$, $15 \mathrm{MPa}$ (solid line) and $12^{\circ}, 20 \mathrm{MPa}$ (dashed line). Especially, the inlet pressure is set to 5 bar in case of cavitation at a high rotational speed. As we can see that the oscillation is speed-dependent but not linear. The highest amplitude, which is about $0.35^{\circ}$ at $2700 \mathrm{rpm}$, may be caused by the resonance frequency of the swash plate control system.

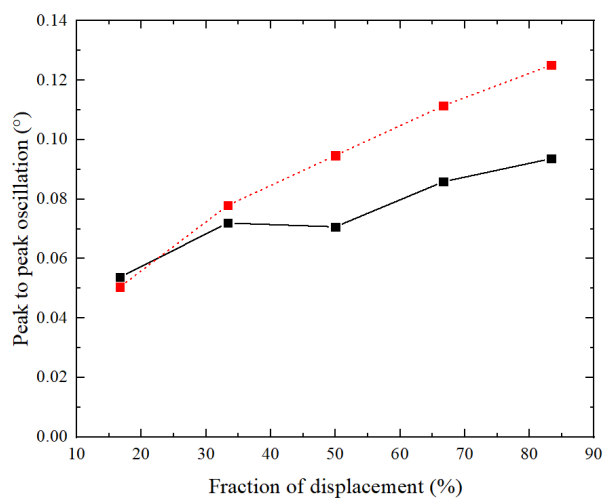

Figure 4: The peak to peak values of swash plate angle under different displacement

The amplitude of the oscillation at the setting angle from $3^{\circ}$ to $15^{\circ}$, which equals the fraction of $16.7 \%$ to $83.3 \%$, is summarized in Figure 4. The solid line and the dashed line represent the swash plate oscillation at $n=1000 \mathrm{rpm}, P_{\text {out }}=15 \mathrm{MPa}$ and $n=1200 \mathrm{rpm}, P_{\text {out }}=15 \mathrm{MPa}$, respectively. The oscillation increases with the increase in displacement.

From the above results, the oscillation of the swash plate is influenced by outlet pressure, rotational speed, and displacement. However, the amplitude with changing pressure and fraction of displacement is rather smaller than that effected by the rotational speed because of the resonance frequency.

\subsection{Effect on pumping dynamics}

In order to investigate the influence of the swash plate oscillation on pressure ripple, efforts have been made to simplify the model with an oscillated swash plate. The model with a fixed swash plate set the swash plate angle as a const value. In this case, the control mechanisms including the control actuator and control valve are omitted. The calculated results of the two different models are presented in Figure 5. The rotational speed is $1000 \mathrm{rpm}$ and the swash plate angle is $12^{\circ}$. The black line and red line represent the outlet pressure with a fixed and an oscillated swash plate, respectively. As we can see that the fixed swash plate shows a larger pressure ripple, compared with the case of the oscillated swash plate.

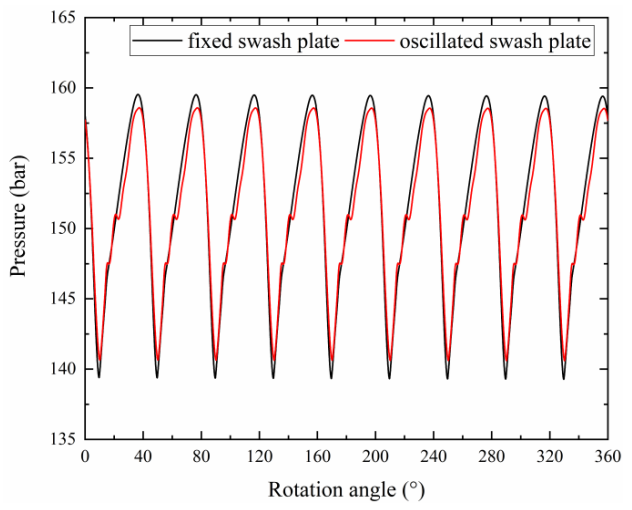

Figure 5: Comparison of pump outlet pressure

\section{Piston motion analysis}

More details are required to account for the pressure ripple reduction. Figure 6 shows the displacement and velocity of one piston for a fixed swash plate and an oscillated swash plate. It's apparent that the oscillated swash plate leads to the vibration of the velocity. And the major difference of the displacement between these can be shown in the enlarged view. At this time, the shaft angle is about $90^{\circ}$ and $180^{\circ}$, where the pressure transition of the piston chamber occurs. Therefore, the oscillation is quite important for analyzing the flow fluctuation and the pressure ripple.

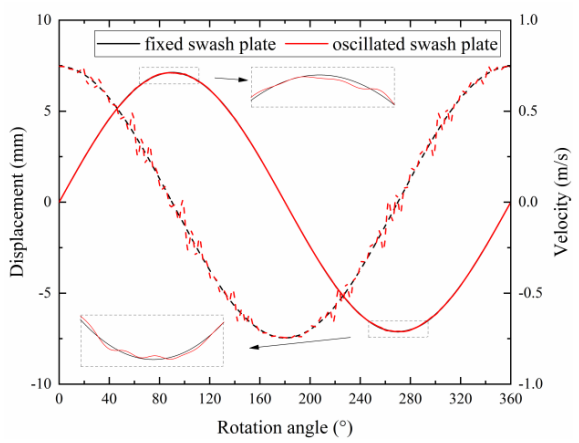

Figure 6: Piston displacement (solid line) and velocity (dashed line) at operation condition: $15 \mathrm{MPa}, 1000 \mathrm{rpm}, 12^{\circ}$ 
Pressure and flow analysis of a single-piston
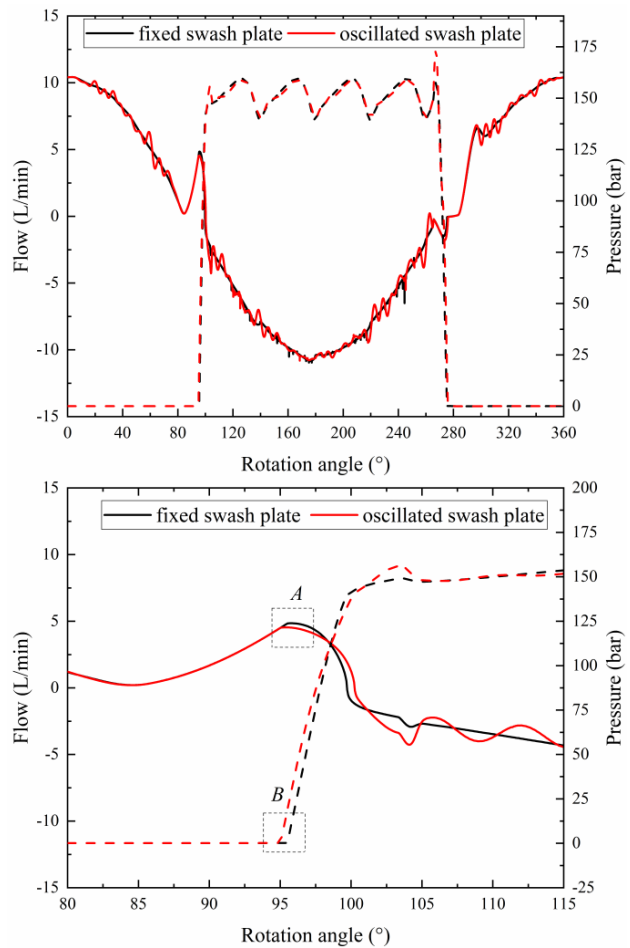

Figure 7: Flow (solid line) and pressure (dashed line) in one piston chamber at operation condition: $15 \mathrm{MPa}, 1000 \mathrm{rpm}, 12^{\circ}$

As illustrated in Figure 7, the pressure in the piston chamber is closely associated with the flow rate in or out of the piston chamber. The pressure with an oscillated swash plate shows larger pressure overshoot at the end of the increasing pressure transition and at the beginning of the decreasing transition. Unfortunately, the pressure overshoot produces large excitation forces and intensifies the vibration of the pump components. What's worse, the load-bearing and lubrication characteristics might be altered due to the variation of the pressure boundary. Regarding the design of the friction pair, the effect of the swash plate oscillation on the pressure boundary should be taken into consideration, especially in a high pressure variable displacement pump.

It also should be noted that there are many small ripples in the flow curve of the oscillated swash plate, which are caused by the vibration of the velocity in Figure 6. Besides, the large backflow in area A is mainly caused by the greater pressure in the discharge port than that in the piston chamber, when the piston starts to connect to the discharge port. It's interesting that the backflow decreases with an oscillated swash plate, which can be explained as an earlier precompression of the piston chamber in area $\mathrm{B}$.

\section{Outlet pressure and flow analysis}

The outlet flow rate is shown in Figure 8. Compared with the outlet pressure in Figure 5, the trend of the flow rate and the pressure is similar. The reduced pressure ripple can be attributed to the decline of the flow fluctuation. The outlet flow rate is the sum of each piston outlet flow. From Figure 8, however, the minimum flow rate around the rotation angle of $100^{\circ}$ is mainly affected by the backflow.

From the above analysis, we can see that the oscillation of the swash plate plays an important role in the assessment of the performance analysis in an axial piston pump. It can be conducted that the oscillated swash plate angle does help the precompression of the piston chamber. It contributes to the reduction of the backflow of each piston. As a consequence, the amplitude of the flow fluctuation and the pressure ripple can be reduced.

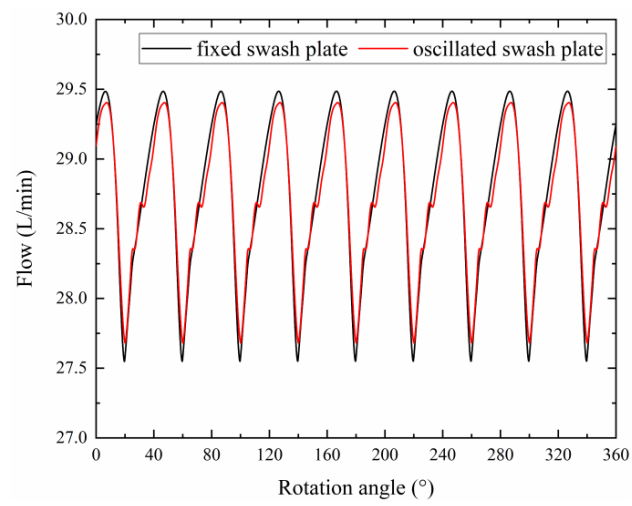

Figure 8: Comparison of pump outlet flow rate

\subsection{Effect on control mechanism}

Considering the control mechanism, the swash plate oscillation also leads to the motion of the actuator piston and counter piston. The pressure in the actuator piston fluctuates in order to counteract the oscillated torque on the swash plate, while the pressure in the actuator piston 
fluctuates almost the same as the outlet pressure. But the variation of flow rate seems to be different from the pressure. Figure 9 shows the flow rates from different chambers. The black, red, and blue line represent the flow rates from the nine piston chambers, the counter piston chamber, and the actuator piston chamber, respectively. And the mean value of the flow rate from nine piston chambers is subtracted from the instantaneous value. The green line represents the load flow rate. The load flow with a green line is a combination of the flow from different chambers besides compression flow.

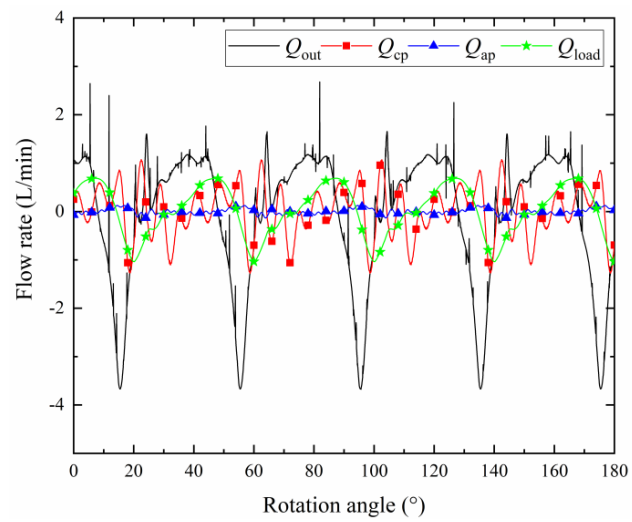

Figure 9: Output flow rate from different chambers at operation condition: $15 \mathrm{MPa}, 1000 \mathrm{rpm}, 12^{\circ}$

As we can see, the flow enters in and out of the counter piston chamber with the changing rotation angle. It can be interpreted as the additional movement of the actuator piston, which caused by the swash plate oscillation. The flow from the actuator piston chamber compensates the leakage across the actuator piston and sleeve. Owing to the larger flow ripple of nine pistons, the pressure ripple is generally decided by the flow from nine piston chambers. But for a variable displacement pump, it may also be influenced by the flow rate from the control mechanism. To be specific, the flow from nine piston chambers is less than the average flow (negative value) around $10-20^{\circ}$ rotation angle. And the counter piston discharges a certain amount of flow rate which balances out the flow fluctuation caused by the nine-piston pump to some extent.

When large oscillation has been taken into consideration, as demonstrated in Figure 10, large flow fluctuation of the counter piston can be found. Especially, the flow from nine piston chamber shows a minimum around $20^{\circ}$ rotation angle. At the same time, the hydraulic oil flows out of the counter piston chamber and reaches a peak value. The larger swash plate oscillation, the larger variation of flow rate from the counter piston chamber. As a result, the load flow fluctuation and pressure are changed.

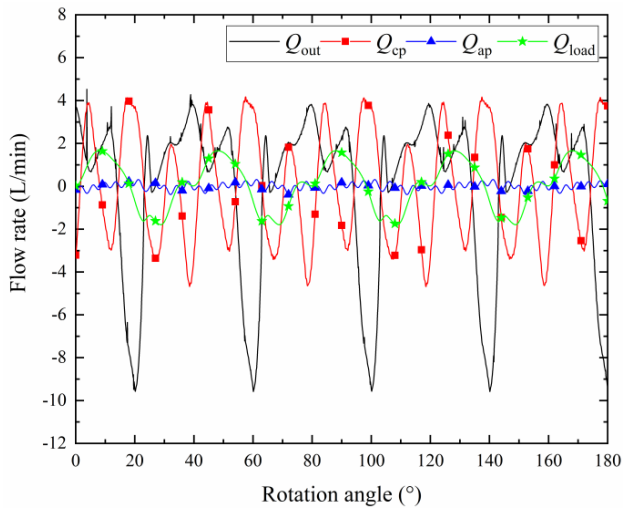

Figure 10: Output flow rate from different chambers at operation condition: $15 \mathrm{MPa}, 1500 \mathrm{rpm}, 12^{\circ}$

\section{CONCLUSION}

In this paper, a mathematical model of a selfsupplied variable displacement axial piston pump is established to investigate the dynamic behavior of the swash plate vibration. In the view of the amplitude, the oscillation is more dependent on the rotational speed than pressure and displacement, which may be caused by the resonance frequency of pump dynamic system. However, the amplitude of swash plate oscillation is small in most situations.

Compared to the fixed swash plate, the piston pump with an oscillated swash plate perform a smaller pressure ripple. Analysis has been conducted to figure out the reason for different performance. The swash plate oscillation influences not only the movements of nine pistons, but also the control mechanism. On the one hand, the additional movement of nine pistons around the relief groove often provides a precompression of the pressure in the piston chamber, which sounds attractive to avoid cavitation during pressure transition. And the fluctuated velocity of the piston causes the ripple in flow curve of a single piston. 
On the other hand, due to the oscillation of the swash plate, additional movement of the counter piston produces a fluctuated flow. In fact, it does contribute to counteracting the fluctuated flow rate caused by the nine pistons. For the reduction of the pressure ripple in a self-supplied variable displacement pump, the effect of the swash plate oscillation on nine pistons and the control mechanism should be taken into account.

\section{ACKNOWLEGEMENTS}

The research was supported by the National Key R\&D Program of China (Grant Number 2018YFB2001100) and the National Natural Science Foundation of China (Grant Numbers 51890882 and 51835009).

\section{NOMENCLATURE}

a Acceleration of the piston $\left(\mathrm{m} / \mathrm{s}^{2}\right)$

$A_{a p} \quad$ Area of the actuator piston $\left(\mathrm{mm}^{2}\right)$

$A_{c p} \quad$ Area of the counter piston $\left(\mathrm{mm}^{2}\right)$

$A_{H P} \quad$ Opening area between the piston chamber and the outlet port $\left(\mathrm{mm}^{2}\right)$

$A_{H P} \quad$ Opening area between the piston chamber and the inlet port $\left(\mathrm{mm}^{2}\right)$

$c_{s w} \quad$ The coefficient of viscous friction $(\mathrm{N} \cdot \mathrm{m} /(\mathrm{rad} / \mathrm{s}))$

C The Flow Coefficient

$d \quad$ Diameter of the piston $(\mathrm{mm})$

$f \quad$ Friction force of the i-th piston (N)

$f_{a p} \quad$ Friction force of the actuator piston (N)

$f_{c p} \quad$ Friction force of the counter piston (N)

$F \quad$ Support force of the i-th piston (N)

$F_{a p} \quad$ Support force of the actuator piston (N)

$F_{c p} \quad$ Support force of the counter piston (N)

$J_{s w} \quad$ Rotary inertia of the swash plate $\left(\mathrm{kg} / \mathrm{m}^{2}\right)$

$k_{v} \quad$ Gain of the control valve

$K_{e} \quad$ Bulk modulus of the fluid (MPa)

$L_{a p} \quad$ Moment arm of the actuator piston (m)

$L_{c p} \quad$ Moment arm of the counter piston (m)

$M_{p} \quad$ Moment of the piston $(\mathrm{N} \cdot \mathrm{m})$

$M_{a p} \quad$ Moment of the actuator piston $(\mathrm{N} \cdot \mathrm{m})$

$M_{c p} \quad$ Moment of the counter piston $(\mathrm{N} \cdot \mathrm{m})$

$n \quad$ Pump shafe speed (rpm)

$N \quad$ Piston numbers

$P_{i} \quad$ Pressure of the i-th piston chamber (MPa)

$P_{\text {in }} \quad$ Inlet pressure (MPa)

$P_{\text {out }} \quad$ Outlet pressure (MPa)

$P_{c} \quad$ Pressure of the actuator piston chamber $(\mathrm{MPa})$

$P_{c p} \quad$ Pressure of the counter piston chamber (MPa)

$Q_{l} \quad$ Flow rate $\left(\mathrm{m}^{3} / \mathrm{s}\right)$

$Q_{\text {in }} \quad$ Inlet flow rate $\left(\mathrm{m}^{3} / \mathrm{s}\right)$
$Q_{o u t} \quad$ The sum of flow rate from nine piston chambers $\left(\mathrm{m}^{3} / \mathrm{s}\right)$

$Q_{a p} \quad$ Flow rate of actuator piston chamber $\left(\mathrm{m}^{3} / \mathrm{s}\right)$

$Q_{c p} \quad$ Flow rate of actuator piston chamber $\left(\mathrm{m}^{3} / \mathrm{s}\right)$

$Q_{\text {load }} \quad$ Load flow rate $\left(\mathrm{m}^{3} / \mathrm{s}\right)$

$R \quad$ Radius of piston around driveshaft (m)

$u \quad$ Control signal

$v \quad$ velocity of the piston $(\mathrm{m} / \mathrm{s})$

$V_{p} \quad$ the volume of the piston chamber $\left(\mathrm{m}^{3}\right)$

$V_{a p} \quad$ the volume of the actuator piston chamber $\left(\mathrm{m}^{3}\right)$

$V_{c p} \quad$ the volume of the counter piston chamber $\left(\mathrm{m}^{3}\right)$

$x_{a p} \quad$ Displacement of the actuator piston (m)

$x_{c p} \quad$ Displacement of the counter piston (m)

$x_{v} \quad$ Spool displacement of the control valve (m)

$z_{i} \quad$ Displacement of the i-th piston $(\mathrm{mm})$

$m_{p s} \quad$ Mass of the piston and slipper $(\mathrm{kg})$

$m_{a p} \quad$ Mass of the actuator piston $(\mathrm{kg})$

$m_{c p} \quad$ Mass of the couter piston and slipper $(\mathrm{kg})$

$\beta \quad$ Swash plate angle (deg)

$\varphi_{i} \quad$ Rotational angle of the i-th piston

$\omega \quad$ Pump shafe speed ( $\mathrm{rad} / \mathrm{s}$ )

$\omega_{v} \quad$ Frequency of the valve $(\mathrm{rad} / \mathrm{s})$

\section{REFERENCES}

[1] Ivantysynova M (2003) Hydrostatic pumps and motors: principles, design, performance, modelling, analysis, control and testing. Tech Books International.

[2] Manring N D. Valve-plate design for an axial piston pump operating at low displacements. Journal of Mechanical Design - Transactions of the ASME[J], 2003, 125(1): 200-205.

[3] Guan C, Jiao Z, He S (2014) Theoretical study of flow ripple for an aviation axial-piston pump with damping holes in the valve plate. Chinese Journal of Aeronautics, 2014, 27(1): 169-181.

[4] Ye S, Zhang J, Xu B, Song W, Chen L, Shi H, Zhu S (2017) Experimental and numerical studies on erosion damage in damping holes on the valve plate of an axial piston pump. Journal of Mechanical Science and Technology, 31(9), 4285-4295.

[5] Kumar Seeniraj G, Ivantysynova M (2011). A multi-parameter multi-objective approach to reduce pump noise generation. International journal of fluid power, 12(1), 7-17.

[6] Zeiger G, Akers A (1985). Torque on the swashplate of an axial piston pump.

[7] Kassem S, Bahr, M K (2000). On the dynamics of swash plate axial piston pumps with conical cylinder blocks. Sixth triennial international symposium on fluid control measurement and visualization. 
[8] Achten P (2013). Dynamic high-frequency behaviour of the swash plate in a variable displacement axial piston pump. Proceedings of the Institution of Mechanical Engineers, Part I: Journal of Systems and Control Engineering, 227(6), 529-540.

[9] Fang X, Ouyang $X$, Yang H (2018). Investigation into the Effects of the Variable Displacement Mechanism on Swash Plate Oscillation in High-Speed Piston Pumps. Applied Sciences, 8(5), 658.

[10] Ericson L (2014). Swash plate oscillations due to piston forces in variable in-line pumps. In
Proceedings of 9th International Fluid Power Conference, Aachen, Germany.

[11] Ericson L (2013). Movement of the swash plate in variable in-line pumps at decreased displacement setting angle. In Proceedings of the 22nd International Congress of Mechanical Engineering, Ribeirão Preto, SP, Brazil (pp. 37).

[12] SCHOEMACKER F, MURRENHOFF H (2019). Interaction Between Swash Plate Movement And Commutation In Axial Piston Machines. JFPS International Journal of Fluid Power System, 11(3), 49-54. 